\title{
PŘÍTOMNOST V NEPŘÍTOMNOSTI Schelling v předmluvě k Fenomenologii ducha aneb metafora absolutna jako noci
}

\section{Jindřich Karásek}

V předmluvě k Fenomenologii ducha existují textové pasáže, které jsou podle standardní interpretace Hegelovou implicitní kritikou Schellingovy identitní metafyziky absolutní substance, implicitní proto, že Schelling zde není výslovně zmíněn. Tento typ vztahu k jinému mysliteli lze označit jako „přítomnost v nepř́tomnosti“. V duchu této interpretace lze říci, že Hegel shrnuje svou kritiku pomocí dvou metafor. První z nich se pokouší vystihnout interní strukturu a povahu absolutní substance. Vychází z toho, že absolutní substance je pojata jako naprostá identita subjektivního a objektivního momentu. Absolutno je proto podle této metafory pojato jako „noc, ve které jsou všechny krávy černé“. ${ }^{1}$ Pojmový význam této metafory je tedy ten, že koncepce absolutní substance jako absolutní identity subjektivna a objektivna neumožňuje dostát rozmanitosti, diferenciaci a konkrétní určitosti jevového světa, a to jak světa přírody, tak světa objektivního ducha. Druhá metafora mírí na absolutní substanci jako na východisko identitního filosofického systému v podobě námitky, že se v něm začíná bezprostředně absolutním věděním jako „Z pistole“. ${ }^{2}$ Problém spatřuje Hegel již v tom, a právě v tom, že absolutno je východiskem, nikoliv teprve závěrečným rezultátem celého systému. Třetím bodem Hegelovy kritiky je pojem intelektuálního názoru. Tento bod souvisí bezprostředně s druhou uvedenou metaforou: stejně jako je výstřel z pistole jednorázovým okamžitým aktem, má být i absolutno v intelektuálním názoru uchopeno bezprostředním jednorázovým aktem. Absolutno má být uchopeno v pocitu či bezprostředně nažreno. Identitní metafyzika absolutní substance si tak chce podle Hegela ušetřit namáhavou diskursivní pojmovou práci.

1 G. W. F. Hegel, Phänomenologie des Geistes, in: Werke, vyd. E. Moldenhauer - K. M. Michel, III, Frankfurt a. M. 1986, str. 22. Český překlad: G. W. F. Hegel, Fenomenologie ducha, přel. J. Patočka, Praha 1960, str. 60. Patočka však překládá: „noc, v níž, jak se říká, je každá kočka černá“. Dále uvádíme odkaz na stránky českého překladu v závorkách.

2 Srv. tamt., str. 31 (česky str. 66). 
Hegel tak stejně jako před ním Kant kritizuje představu, že diskursivní pojmové myšlení lze nahradit intuicí, pocitem apod. Tuto kritiku ovšem Hegel rozšiřuje způsobem, s nímž by Kant již souhlasit nemohl. Tvrdí totiž, že absolutno lze prostřednictvím diskursivního pojmového myšlení nejen myslet, ale i poznat, či přesněji řečeno: právě proto, že lze absolutno myslet diskursivně pomocí pojmů, lze je poznat. Myslet v pojmech znamená podle Hegela poznat. Hegel tím ruší smysl Kantovy distinkce mezi myšlením a poznáním, a výrazně tím reviduje význam nejen intelektuálního, ale i smyslového názoru pro proces poznávání, jak o tom svědčí již dialektika smyslové jistoty jakožto první bezprostřední podoby vědomí ve Fenomenologii ducha.

Druhá metafora se zdá postihovat alespoň do určité míry Schellingův identitní systém, protože jeho východiskem je skutečně definice absolutní substance jakožto bezprostředního intuitivního poznání vlastní identity, byt' tato substance prochází vývojem, jejž sama iniciovala, takže je sice východiskem, ale také rezultátem systému. Lze však ukázat, že adresátem Hegelovy první kritické metafory není Schelling. A dále lze ukázat, že Schelling je v předmluvě k Fenomenologii ducha prŕitomně nepř́tomný i v pozitivním smyslu. Své první jenské spisy koncipuje Hegel pod dominantním vlivem právě Schellingovy identitní filosofie, a přestože je Fenomenologie ducha nesporně zcela samostatným a novátorským filosofickým výkonem, vliv Schellingova myšlení je patrný i zde, byt' nikoliv na první pohled, a dokonce lze doložit, že by ho Hegel bez většího zaváhání připustil.

Vliv Schellingovy identitní metafyziky na raného jenského Hegela lze ukázat na tom, jak Hegel ve spisu Vira a věděni (Glauben und Wissen) zr. 1802 interpretuje Kantovo řešení hlavní kritické otázky: „Jak jsou možné syntetické soudy a priori?" Hegel svou interpretaci shrnuje v této pasáži:

„Jak jsou možné syntetické soudy a priori? Tento problém nevyjadřuje nic jiného než ideu, že v syntetickém soudu jsou subjekt a predikát - subjekt jako zvláštní, predikát jako obecné, subjekt ve formě bytí, predikát ve formě myšlení -, tyto nestejnorodé [momenty] zároveň a priori, tj. absolutně identické. Možností tohoto kladení je pouze rozum, jenž není ničím jiným než identitou těchto nestejnorodých momentů. ... Tak Kant vpravdě vyřešil svou otázku: jak jsou 
syntetické soudy a priori možné; jsou možné na základě původní absolutni identity nestejnorodého, ze které jakožto nepodmíněného se ona sama rozlišuje jakožto co do formy soudu se odděleně jevící subjekt a predikát, zvláštní a obecné.“3

V pasáži se na dvou místech vyskytuje termín „absolutní identita“, tj. přesně ten termín označující v Schellingově identitní metafyzice pojem, jímž v tomto období svého myšlenkového vývoje definuje absolutní substanci. Tak v § 12 Podání mého systému filosofie (Darstellung meines Systems der Philosophie) z r. 1801, v prvním spisu identitně-filosofického období, ${ }^{4}$ stanovuje Schelling tento obecně-ontologický princip: , Vše, co jest, je absolutní identita sama. ${ }^{\text {"5 }}$ Zohledníme-li navíc, co říká Schelling v následujících paragrafech, získáme hlavní teze, na nichž Hegel staví svou interpretaci. Nejprve v $\S 19$ řekne: „Absolutní identita je pouze pod formou poznávání své identity se sebou samou. Nebot' její poznávání je právě tak původní jako forma jejího bytí (§ 18), ba je to forma jejího bytí sama (tamtéž, Dodatek 1).“6 Absolutní identita je základem všeho, co jest, přičemž její bytí je zároveň jejím poznáním. Poznáním se zde míní

3 G. W. F. Hegel, Glauben und Wissen oder die Reflexionsphilosophie der Subjektivität, in der Vollständigkeit ihrer Formen, als Kantische, Jacobische und Fichtesche Philosophie, in: S. Dietzsch (vyd.), Kritisches Journal der Philosophie, Westberlin 1985, str. 265, resp. 267 n. Kurziva J. K.

4 Jak upozorňuje Xavier Tilliette, pojem intelektuálního názoru se v tomto spisu nevyskytuje, a Schelling je tomu dodatečně dokonce rád, nebot’ toto „,kanonické“" pojednání se díky tomu vyhne Hegelově námitce v podobě metafory o výstřelu z pistole. Srv. X. Tilliette, Untersuchungen über die intellektuelle Anschauung von Kant bis Hegel, Stuttgart-Bad Cannstatt 2015, str. 273. Adjektivum „kanonické“ dává do uvozovek Tilliette, nebot' o tomto spisu tvrdí, že je to nepodařený a ve spěchu sepsaný elaborát. Podíváme-li se na jiné Schellingovy spisy předmětného období, tj. na spisy z let 1801-1806, nelze s tím než souhlasit. Schelling nicméně, pokračuje Tilliette, má pro tento spis podobnou slabost jako rodič pro nejslabší ze svých dětí. A absence pojmu intelektuálního názoru v tomto spisu později Schellingovi nebrání v tom, aby intelektuální názor obhajoval jako neodstranitelný orgán filosofického vědění. Připomeneme-li si, že pojem intelektuálního názoru absentuje také ve Fichtově prvním vědosloví z let 1794-1795, ukáže se, že dva hlavní zastánci pojmu intelektuálního názoru v německé pokantovské filosofii měli k tomuto pojmu ambivalentní postoj, daný patrně strategickými důvody. Kant pojem intelektuálního názoru, jak známo, odmítal, a Hegel zaujme nejpozději od Fenomenologie ducha podobný postoj, kladoucí hlavní důraz na diskursivitu pojmu.

5 Srv. F. W. J. Schelling, Výbor z dilla. Rané spisy, přel. J. Patočka - M. Petř́iček, Praha 1990, str. 306.

6 Srv. tamt., str. 308. 
sebepoznání: absolutní identita ,jest pouze pod formou poznávání své identity se sebou samou“".7 Toto sebepoznání vlastní identity však předpokládá diferenciaci, jak Schelling konstatuje v § 21: „Absolutní identita nemůže nekonečně poznávat sebe samu, aniž by se nekonečně kladla jako subjekt a objekt." ${ }^{\text {8 }}$ Aby se tedy mohla absolutní identita poznat ve své identitě, musí se diferencovat na subjekt na jedné straně, a na objekt na straně druhé. Tato věta je podle Schellinga zřejmá sama sebou, a to patrně proto, že každý akt poznání jako takový předpokládá diferenciaci na poznávající subjekt a poznávaný objekt. Konečně v § 22 se Schelling opře o subjekt-predikátovou strukturu: ,V této větě [ve větě $\mathrm{A}=\mathrm{A}$ ] je však jedno a totéž A kladeno na místo predikátu i subjektu. “9 To lze interpretovat způsobem, který naznačuje Hegelova interpretace Kantova řešení hlavní kritické otázky: absolutní identita se v subjekt-predikátové struktuře diferencuje tak, že se v ní klade na subjektové straně ve formě bytí a na predikátové straně ve formě myšlení, což znamená, že absolutní identita kladoucí sebe samu na subjektové straně jako bytí se klade na predikátové straně jako myšlená sebou samou. Soud je tedy sebediferenciací absolutní identity na nestejnorodé momenty, subjekt a predikát. ${ }^{10}$

7 Srv. tamt.

8 Srv. tamt. Reinhard Lauth upozorňuje právem na to, že: „Nejdůležitější krok, jehož prostřednictvím získává Schelling diferenci, je ten, že toto poznání identity pojímá jako sebepoznání.“ To, co na začátku zavedl jako něco, čemu chybí bytí pro sebe, tak Schelling nyní pomocí tohoto bytí pro sebe domýšlí. Srv. R. Lauth, Hegel vor der Wissenschaftslehre, Stuttgart 1987, str. 30. Titul Lauthovy knihy není pochopitelně míněn časově, nýbrž tak, že Hegel, jenž podrobuje Fichtovo vědosloví velmi ostré, avšak podle Lautha neoprávněné kritice ve spisu Diference Fichtova a Schellingova systému filosofie z r. 1801 (celý titul v originále zní: Differenz des Fichte'schen und Schelling'schen Systems der Philosophie in Beziehung auf Reinhold's Beyträge zur leichteren Übersicht des Zustands der Philosophie zu Anfang des neuzehnten Jahrhunderts), má být přiveden před opravdovou podobu Fichtova vědosloví a konfrontován s ním. Byt' lze souhlasit s tím, že Hegelova kritika Fichtova vědosloví v tzv. Spisu o diferenci není oprávněná, a to už proto, že Hegel v té době neměl vědosloví prostudované, je třeba na druhou stranu říci, že mnohé Lauthovy formulace prozrazují jeho poměrně velkou averzi vůči Hegelovi, což není dobrý hermeneutický prostředek. O tom, že raný jenský Hegel je pod dominantním vlivem Schellingovy identitní koncepce, není pochyb. Lauth dokonce říká, že se musíme ptát, zda se Hegel od Schellinga v tomto období vůbec nějak odlišuje a zda Hegel nebyl jen, jak to formuloval Reinhold, Schellingovým ,štítonošem“ (Schildknappe). Srv. R. Lauth, Hegel vor der Wissenschaftslehre, str. 12 n.

9 Srv. F. W. J. Schelling, Výbor z díla. Rané spisy, str. 308.

10 Schelling má zjevně na mysli analytickou propozici. Syntetické propozice ve formě „A je B“ jsou odvozeny z této základní analytické propozice pomocí pojmu pouhé kvantitativní diference subjektu a predikátu jakožto výrazů subjektivna 
Touto absolutní identitou je jak pro Schellinga, tak Hegela rozum (Vernunft), a proto je definována jako absolutní sebepoznání.

Konrad Cramer ukazuje - poměrně překvapivě -, že Kant by mohl citované Hegelovy věty vskutku odsouhlasit jako výstižnou interpretaci svého řešení hlavní kritické otázky. ${ }^{11}$ Naopak nesouhlasně by se Kant stavěl k této koncepci v okamžiku, kdy Hegel vtáhne do hry svou vlastní systematickou premisu, která je zcela klíčová pro jeho zralé pojetí ducha, totiž premisu, která hovoří o seberozlišování původní absolutní identity: v syntetickém soudu a priori se diferencuje původní absolutní identita na subjekt a predikát, na zvláštní a obecné, na bytí a myšlení. ${ }^{12}$ Vzhledem k citovaným paragrafům z Podání mého systému filosofie je tedy zřejmé, že to byla Schellingova identitní metafyzika, kterou Hegel při své interpretaci Kanta aplikuje a která do Hegelovy interpretace vnáší moment disentu s Kantem. Je zřejmé, že Kantova transcendentální apercepce není entitou, o níž by mohlo platit, že se jakožto absolutní

a objektivna, jež jsou diferentními momenty absolutní identity. Termín ,absolutní identita“ je poněkud matoucí, protože se zjevně jedná o takovou identitu, jež je interně strukturována diferencí. Oba tyto problémy se objevují v Hegelově interpretaci Kantova řešení hlavní kritické otázky. První problém má svůj původ u Kanta: syntetický soud a priori je nutným spojením subjektu a predikátu, jehož nutnost však nelze zdůvodnit principem sporu. Syntetický soud a priori tak sice vykazuje vlastnost analytické propozice, avšak vyžaduje zcela jiné zdo̊vodnění.

11 Srv. K. Cramer, Spekulatives Denken und synthetisches Urteil a priori, in: Zeitschrift für philosophische Forschung, 51, 1997, str. 509. Cramer ukazuje, že Hegelovy věty lze převést na čtyři teze, s nimiž by Kant mohl souhlasit: (i) v syntetickém soudu a priori jsou subjekt a predikát nestejnorodé momenty; (ii) v syntetickém soudu a priori jsou subjekt a predikát nestejnorodé momenty potud, že subjekt je tím zvláštním a predikát tím obecným; (iii) v syntetickém soudu a priori jsou subjekt a predikát nestejnorodé momenty potud, že subjekt je ve formě bytí a predikát ve formě myšlení; (iv) v syntetickém soudu a priori jsou tyto nestejnorodé momenty původně identické. Srv. tamt., str. 514. Teze (iv) vyjadřuje základní problém spojený s Kantovou koncepcí syntetických apriorních propozic. Je patrné, že Schelling a Hegel z toho odvodili jeden ze základních problémů filosofie, totiž myslet substanci (= rozum) jako absolutní identitu, jež má přesto být interně diferencovaná na nestejnorodé momenty. Tento problém bychom mohli označit jako problém „netriviální identity“. Jako pokus o jeho řešení zavádí Schelling pojem indiference. Srv. Podání mého systému filosofie § 1: „Rozumem nazývám absolutní rozum čili rozum, pokud je myšlen jako naprostá indiference subjektivního a objektivního.“ (F. W. J. Schelling, Výbor z dila, str. 305). Pro Hegela, jak bylo patrné z citátu z Víry a vědění, je identita absolutní tehdy, je-li apriorní. Termín absolutní tak vyjadřuje původ, nikoliv strukturu.

12 Srv. K. Cramer, Spekulatives Denken und synthetisches Urteil a priori, str. 535 . 
identita v syntetickém soudu diferencuje na subjekt a predikát, na bytí a myšlení. Navíc je touto absolutní identitou, tj. transcendentální apercepcí, rozum, který Hegel ve Víre a vědění identifikuje s transcendentální obrazotvorností. ${ }^{13}$

II.

Lze doložit, že tuto myšlenku sebediferencující se identity podržuje Hegel i v předmluvě k Fenomenologii ducha. Doložit to lze na zpưsobu, jak Hegel interpretuje Fichtův teorém sebekladení. V jedné pasáži Hegel píše:

„Živá substance je dále bytí, které je vpravdě subjekt, či - což je totéž - je vpravdě skutečným jen potud, pokud je pohybem sebekladení čili zprostřredkováním mezi přechodem sebe $\mathrm{v}$ jiné bytí a sebou samým [Sichanderswerden mit sich selbst]. Jakožto subjekt jest ryzí jednoduchá zápornost, a právě tím je rozdvojením jednoduchého či zdvojením vytvářejícím protiklad." ${ }^{14}$

Substance je subjekt, a jako taková je živoucí a skutečná pouze jako neustálý pohyb kladení sebe sama. Tento pohyb interpretuje Hegel jako „zprostředkování sebezjinačení“. Tomu lze rozumět tak, že sebekladení je zároveň kladením jinakosti, tato jinakost je jinakostí sebekladoucí se substance, přičemž zprostředkování znamená návrat z této jinakosti zpět k sobě: ,zjinačení, které musí být odvoláno - je zprostředkování.“15 Jde o „reflexi v sebe, která se děje v jinakosti“"16 (Reflexion im Anderssein in sich selbst), a tím je rovnost (Gleichheit), tj. identita opět ustavena (wiederhergestellt). Identita, $\mathrm{tj}$. jednoduchost, se tak sama rozdvojuje, toto rozdvojení překonává a vrací se k sobě jako k identitě. Přesně tato struktura sebepohybu substance byla, jak jsme viděli, myšlena v Schellingově identitní koncepci. Schellingova absolutní substance poznává sebe samu tím, že se klade jako rozdvojená na subjekt a objekt, čemuž odpovídá v soudu rozdvojení na subjekt a predikát, a protože její sebepoznání je

13 Srv. G. W. F. Hegel, Glauben und Wissen, str. 268 n. Hegel tak do určité míry předjímá Heideggerovu interpretaci transcendentální obrazotvornosti.

14 Srv. týž, Phänomenologie, str. 23 (česky str. 61).

15 Srv. tamt., str. 25 (česky str. 62).

16 Srv. tamt., str. 23 (česky str. 61). 
poznáním její identity (rovnosti se sebou), musí být rozdvojení opět vzato zpět. Tato substance tak neustále pulsuje oním pohybem sebezjinačení a jeho vzetí zpět, jímž se znovu ustavuje identita. Popíšeme-li tuto strukturu staticky, můžeme říci, že je identitou identity a neidentity.

Je tedy otázkou, zda metaforou noci, ve které jsou všechny krávy černé, může Hegel mínit Schellinga. V souvislosti s touto metaforou mluví Hegel o ,jednobarevném formalismu, který dochází toliko k rozdílu v látce, a to tím, že tento rozdíl je již připraven a známý “ ${ }^{17}$ Tento formalismus je „beztvaré opakování téhož, aplikované zvenčí na různý materiál “. ${ }^{18}$ At' už Hegel kritizuje Schellinga za cokoliv, nemůže tímto jednobarevným formalismem mínit jeho identitní filosofii. Manfred Frank i s odkazem na Jaspersovu knihu o Schellingovi ${ }^{19}$ ukazuje, že samu metaforu noci přejímá Hegel od Schellinga. Schelling její pomocí kritizuje ty, kteří v podstatě absolutna nevidí nic než prázdnou noc a nedokáží v něm nic poznat. Frank dokonce upozorňuje na to, že i jiné Hegelovy metafory z předmluvy (např. metafora bakchantického reje) mají svůj původ u Schellinga. Tyto metafory se objevují v Schellingovu spisu Dalši podání ze systému filosofie z r. 1802, takže, zvažuje Frank, se zdá, že Hegel tento Schellingův spis používal při sepisování předmluvy. Rovněž identifikace substance a subjektu má svůj původ v tomto Schellingovu spisu. ${ }^{20}$ Podle Xaviera Tillietta jsou např. teze, že pravdivým je celek, substance je také subjektem, nepravda je momentem pravdy, „vykovány v dílně identitní filosofie““.21

V této souvislosti je třeba zmínit Hegelovo užití metafory noci v encyklopedické logice. V 1. dodatku k § 24 ji Hegel aplikuje na pojem Já následujícím způsobem:

„Já je bytí-pro-sebe, v němž je všechno zvláštní překonáno a negováno, je to to poslední, jednoduché a čisté našeho vědomí. ... Já je tato prázdnota, toto receptaculum pro vše a cokoli, pro které vše je a které vše v sobě uchovává. Každý člověk je celý svět pohřbených představ

17 Srv. tamt., str. 21 (česky str. 60).

18 Srv. tamt. (česky str. 59).

19 K. Jaspers, Schelling. Größe und Verhängnis, München 1955.

20 Srv. M. Frank, Der unendliche Mangel an Sein. Schellings Hegelkritik und die Anfänge der Marxschen Dialektik, München 1992², str. 152 n., pozn. 6.

21 Srv. X. Tilliettte, Schelling. Biographie, přel. S. Schaper, Stuttgart 2004, str. 163. Stejně jako Frank upozorňuje i Tilliette na to, že metaforu absolutna jako noci přejímá Hegel od Schellinga. Srv. tamt., str. 166. 
v temnotě Já. Tak je Já všeobecnem, v němž se abstrahuje od všeho zvláštního, v němž je ale zároveň zahaleně obsaženo vše zvláštní."22

Slovo „temnota“ zvolil překladatel pro překlad slova „Nacht“ - „,noc“. 23 Já je tedy nocí, jež je hrobem představ. Všechny představy jsou v něm stejně černé. Podíváme-li se však na text podrobněji, ukáže se, jak máme tomuto pohřbení rozumět. V Já se sice abstrahuje od všeho zvláštního, avšak vše zvláštní je v něm obsaženo zahaleně (verhüllt). To je pochopitelně opět metafora. Její smysl lze odhalit, když si všimneme, že Hegel pro pojmový popis této zahalenosti použivá své charakteristické pojmy: Já v sobě vše zvláštní uchovává (aufbewahren) jako negované a překonané (aufgehoben). „Uchovávat“ je pro Hegela jeden z významů slovesa ,aufheben“. Není to ovšem Hegelovo znásilnění jazyka. Hegel má pravdu, když v dodatku $\mathrm{k} \S 96$ konstatuje dvojí význam německého slovesa ,aufheben“: „,Překonáním’ rozumíme jednak zrušení, negování, a podle toho říkáme, např. že nějaký zákon, ustanovení atd. bylo zrušeno (aufgehoben). Dále však znamená ,překonání' také uchování, a v tom smyslu říkáme, že něco bylo uchováno (aufgehoben). “ ${ }^{24}$ Představy tedy nejsou v noci Já zrušeny či škrtnuty, jako když se zruší - anuluje - nějaký zákon, nýbrž jsou v ní zároveň uchovány, jako když uchováváme máslo v ledničce.

Je sice možné, že Hegel zde používá metaforu noci jinak než v předmluvě k Fenomenologii ducha, ba je to dokonce pravděpodobné, protože pokud by bylo zvláštní obsaženo $\mathrm{v}$ absolutnu tak, jak jsou obsaženy představy v noci Já, nebylo by možné tvrdit, že všechny zvláštní věci by v něm byly stejně černé, tak jako nikdo neřekne, že ve své ledničce nedokáže odlišit máslo od mléka, šunky apod. Avšak právě: zeptáme-li se, jakým způsobem budou rozvinuty zvláštní věci z jejich zahalené přítomnosti v temnotě Já do jejich konkrétní zvláštnosti jasného dne, můžeme odpovědět, že se tak stane diferenciací Já samého, což se může podle

22 G. W. F. Hegel, Malá logika, přel. J. Loužil, Praha 1992, str. 74 n.

23 „Ich ist das reine Fürsichsein, worin alle Besonderheiten negiert und aufgehoben sind, dieses Letzte, Einfache und Reine des Bewusstseins. ... Ich ist diese Leere, das Rezeptakulum für alles und jedes, für welches alles ist und welches alles in sich aufbewahrt. Jeder Mensch ist eine ganze Welt von Vorstellungen, welche in der Nacht des Ich begraben sind. So ist denn Ich das Allgemeine, in welchem von allem Besonderen abstrahiert ist, in welchem aber zugleich alles verhüllt liegt." Srv. G. W. F. Hegel, Enzyklopädie der philosophischen Wissenschaften im Grundrisse (Erster Teil. Die Wissenschaft der Logik mit mündlichen Zusätzen, 1830) in: Werke, VIII, str. 83.

24 Srv. G. W. F. Hegel, Malá logika, str. 184 n. 
Hegelovy rané interpretace Kantovy odpovědi na hlavní kritickou otázku odehrávat v syntetických propozicích. Tato interpretace však, jak jsme výše upozornili, již není kantovská. Kurzivou zdůrazněná věta, podle níž je každý člověk ,celý svět představ pohřbených v noci Já“, naznačuje, že Hegel v citované pasáži spojuje Kantův teorém Já, pro něž vše, co má Já moci poznat, musí být, a Já toto vše do sebe přijímá v aktech syntéz, s Leibnizovou koncepcí monády, která je celým světem, a vše, co je pro ni, se vynořuje z ní samé jako z noci, $v$ níž je toto vše původně pohřbeno, tj. uchováno. Hegel tuto charakteristiku monády sám zdůrazňuje v § 194: $\mathrm{v}$ jednoduché jednotě monády ,je veškerý rozdíl pouze ideální, nesamostatný. Zvenčí do monády nic nepřichází, monáda je v sobě celým pojmem a liší se jen podle jeho vlastního většího nebo menšího rozvinutí'“.25 V této souvislosti je třeba zmínit, že v dialogu Bruno z r. 1802 identifikuje Schelling strukturu absolutna, rozvinutou v Podání mého systému filosofie, totiž identitu subjektivna a objektivna s absolutním Já, jež je formou všech forem, či přesněji řečeno, absolutní Já je syn zrozený z absolutna, jenž je s ním stejně věčný a má s ním identickou podstatu (Wesen). Pokud bychom přijali, že absolutní Já je základem konečné subjektivity, mohli bychom říci, že můžeme absolutno poznat, nebot' je již vždy „u nás“. ${ }^{26}$ Tato charakteristická Hegelova teze z předmluvy k Fenomenologii ducha tak má svůj předobraz v Schellingově dialogu Bruno.

Hegelův náhled na problematiku Já se ovšem vyvíjí souběžně s tím, jak se vyvíjí jeho názor na Kanta. Od spíše odmítavého postoje raných jenských spisů až po poměrně afirmativní postoj ve Vědě o logice: „Patří k nejhlubším a nejsprávnějším náhledům, jež se nacházejí v Kritice rozumu, že jednota, jež tvoří podstatu pojmu, je poznána jako pưvodni syntetická jednota apercepce, jako jednota onoho ,Já myslím’ neboli sebevědomí.“27

Pokud je naše interpretace správná, pak v logice pojímá Hegel sám Já jako noc, a to blíže v tom smyslu, že všechny zvláštní věci jsou v Já zavinutě či zahaleně obsaženy, a lze je z Já rozvinout na základě aktu jeho vlastní sebediferenciace. Ve výše uvedeném citátu Hegel mluvil o tom, že zvláštní je v Já obsaženo jako překonané, a tudíž uchované. To lze patrně interpretovat jednoduše tak, že zvláštní je přijato do všeobecnosti Já a proměněno ve svůj pojem, avšak v pojmu musí být zvláštnost zvláštního uchována, aby bylo možno odlišit jeden pojem od druhého.

25 Srv. tamt., str. 323.

26 K tomu srv. X. Tilliette, Schelling, str. 171.

27 Srv. G. W. F. Hegel, Wissenschaft der Logik, II, in: Werke, VI, str. 254. 
Tudíž ani v pojmy překonané zvláštní „věci“ nemohou být v Já obsaženy jako v té noci, ve které jsou všechny krávy černé. Zvláštní se tak jakožto pojem stalo obsahem Já, $v$ němž je pohřbeno, tj. obsaženo tak, že na ně není zaměřena tematická reflexe Já. Opětovné rozvinutí zvláštního má potom charakter tematické reflexivní zaměřenosti na obsahy Já, a jelikož to jsou obsahy Já, znamená jejich tematické rozvíjení reflexivní sebediferenciaci Já samého. Můžeme tedy s Konradem Cramerem říci, že myšlenka sebediferencující se absolutní identity je charakteristická pro zralou Hegelovu filosofii.

Tento postup sebediferenciace odpovídá v předmluvě k Fenomenologii ducha myšlence, kterou Hegel staví proti monotónnímu či jednobarevnému formalismu, jenž v beztvarém opakování podrobuje vše absolutní ideji. Tato myšlenka říká, že šíře (Ausbreitung) zvláštního obsahu má být získána tím, že jedno a totéž se samo rozmanitým způsobem utváŕí (gestaltet) ${ }^{28}$ Hegel ji rozvíjí dál v pojmu Já jako „moci negativna“ (Macht des Negativen), jehož imanentní pohyb spočívá v tom, že to, co je fixní, známé a upevněné, proměňuje v pojmy. ${ }^{29}$ Zatímco tedy monotónní formalismus podrobuje zvláštní absolutní ideji, a připravuje ho tak o jeho zvláštní určitost - a proto pluralita zvláštního mizí v absolutnu jako v noci, ve které jsou všechny krávy černé -, je zvláštní v Já překonáváno, tj. uchováno v podobě pozvednuté na pojem, v němž se specifická určitost zvláštního neztrácí, nýbrž zachovává ve formě obecnosti.

V dodatku k $§ 103$ encyklopedické logiky hájí Hegel Schellingovu myšlenku, kterou Schelling prezentuje již v Podání mého systému filosofie. Tato myšlenka říká, že mezi subjektem o objektem nemůže být kvalitativní, ale jen kvantitativní diference. Důvod je zřejmý: subjekt a objekt jsou jen momenty sebediferencující se absolutní identity, jež je na nich nezávislá a jež je v obou stejně nepodmíněná. ${ }^{30}$ Právě o tuto myšlenku by se mohla oprít výhrada z monotónního formalismu: vše, co je, je na základě sebediferenciace absolutní identity, jež se liší na subjekt a objekt, a jelikož mezi nimi není kvalitativní, ale jen kvantitativní diference, je vše, co je, připraveno o svá kvalitativní určení, a je proto ponořeno do noci, ve které je mezi jednotlivými krávami pouze kvantitativní diference, takže mohou sice být větší nebo menší, ale jinak jsou všechny stejně černé. Hegel v uvedeném dodatku mluví o abstraktním rozvažování, jež považuje extenzivní velikost za jedinou formu kvantity,

28 Srv. G. W. F. Hegel, Phänomenologie, str. 21 (česky str. 59).

29 Srv. tamt., str. 37.

30 Srv. F. W. J. Schelling, Výbor z díla, § 23, str. 308. 
a neuznává intenzivní velikosti v jejich specifické určitosti. ${ }^{31} \mathrm{~A} v$ této souvislosti řekne:

„Jestliže se mezi výtkami na adresu novější filozofie zvlášt' často vyskytuje předhůzka, že tato filozofie redukuje vše na identitu, a jestliže se jí proto také dostalo posměšného jména ,filozofie identity', pak z našeho výkladu vyplývá, že právě tato filozofie požaduje, aby se rozlišovalo to, co je jak podle pojmu, tak podle zkušenosti odlišné.“32

Hegel má zjevně na mysli Schellingovu identitní filosofii, přičemž, jak patrno, toto označení bylo používáno Schellingovými odpůrci pejorativně. $Z$ textu je zřejmé, že pozdní Hegel odmítá explicitně, že by výhradu z formalismu, jenž veškeré intenzivní velikosti, např. barvy, redukuje na extenzivní, a ruší je tak v jejich specifické odlišnosti, bylo možno vznášet smysluplně vůči Schellingově identitní filosofii. Nelze však vyloučit, že v roce 1806 smýšlel Hegel ještě jinak, a že tudíž monotónním formalismem přece jen míní Schellinga.

\section{III.}

Otázkou tedy nyní je, zda má Hegel monotónním formalismem na mysli Schellingovu identitní filosofii. Když v předmluvě hovoří o „přírodně-filosofickém“ formalismu, pak se zdá, že se toto podezření jen potvrzuje. Hegel by měl konkrétně na mysli Schellingovu identitní koncepci př́irody. Nejprve je však třeba upozornit na jednu z nejcharakterističtějších myšlenek Fenomenologie ducha, totiž na myšlenku, že substanci je třeba pojmout také jako subjekt, kterou, jak upozornili Manfred Frank a Xavier Tilliette, převzal Hegel od Schellinga. Po dlouhé pasáži, ve které popisuje postup př́rodně-filosofického formalismu, ji Hegel dává do souvislosti se zmíněným procesem překonání zvláštního, jež je uchováním jeho specifické určitosti v živlu obecnosti pojmu, řečeno s Hegelem:

„Tím, že - jak shora vyjádřeno - substance jest o sobě subjektem, je vůbec veškerý obsah svou vlastní reflexí v sebe. Trvání či substance určitého jsoucna [Dasein] je rovnost sobě [Sichselbstgleichheit]; nebot'

31 Srv. G. W. F. Hegel, Malá logika, str. 196. Abstraktním rozvažováním má Hegel na mysli empiristickou prŕrodovědu.

32 Srv. tamt., str. $196 \mathrm{n}$. 
jeho nerovnost se sebou by byla jeho zrušením [Auflösung]. Rovnost sobě je však čirá abstrakce; abstrakce je však myšlení. Vyřknu-li slovo kvalita, říkám tím jednoduchou určenost; kvalitou se liší jedno jsoucno od jiného či je jedním jsoucnem; je pro sebe samo čili trvá touto jednoduchostí vůči sobě. Tím je však bytostně myšlenkou. V tom je obsaženo to, že bytí je myšlení; v tom je obsažena myšlenka, která, jak se zdá, uniká obvyklému nepojmovému ${ }^{33}$ mluvení o identitě myšlení a bytí. “34

Z hlediska sledovaného problému zde není podstatné ani tolik to, že základním výkonem substance jakožto subjektu je myšlení, jež je sebereflexí, na jejímž základě jsou specifické určitosti zvláštního pozvedávány na kategorie bytí (např. kvalita), a že jsoucno je pouze, pokud mu přísluší kategorie kvality, a že myšlenka je tedy bytím, nebo bytí myšlenkou, a že to, co neproblematickému mluvení o identitě bytí a myšlení uniká, je právě ona prostředkující sebereflexe, jež tuto identitu teprve ustavuje. Podstatné je trvání na soběrovnosti, tj. na identitě. Viděli jsme, že Schelling v Podání mého systému filosofie rozvinul, když ne stejnou, tedy alespoň velmi obdobnou představu: naprostá identita subjektivna a objektivna je základem všeho, co je; tato identita je zároveň identitou bytí a poznávání. Za tímto účelem musí identita procházet procesem sebediferenciace na subjekt a objekt, tj. to, co je v ní nejprve bezprostředně identické, musí aktem tematické sebereflexe odlišit, takže její identita se potom odehrává vztahem k jinakosti, neboli není statická, nýbrž je stálým děním či výkonem identifikace. Dále jsme upozornili na to, že ještě v Dalšich podáních ze systému filosofie identifikuje Schelling tuto identitu jako absolutní Já. I Hegel ztotožňuje zmíněnou moc negativna s rozvažováním, a tedy s čistým Já: je to „energie myšlení, čistého já“ 35 Tudíž se vskutku potvrzuje, že Schelling již v r. 1801 pojímá substanci, základ všeho jsoucího, jako subjekt.

Když se nyní podíváme, co Hegel říká o přírodně-filosofickém formalismu, bude se jevit velmi nepravděpodobným, že by tím mohla být míněna Schellingova identitní metafyzika př́rody. Přírodně-filosofický formalismus učí, že „rozvažování je elektř̌ina, nebo že zvíře je dusík, nebo že se rovná jihu či severu atd“. ${ }^{36}$ Aniž by bylo třeba to nějak zvlášt'

33 V originálu „,begriffloses Sprechen“, což může znamenat také „nechápající mluvení“. Míněno by potom bylo takové mluvení, které neví, o čem mluví.

34 Srv. G. W. F. Hegel, Phänomenologie, str. 53 (česky str. 81).

35 Srv. tamt., str. 36 (česky str. 69).

36 Srv. tamt., str. 49 n. (česky str. 78). 
dokládat na Schellingových textech předmětného období, je evidentní, že se spíše jedná o nezáměrnou parodii Schellingovy filosofie př́rody, jejímž autorem pochopitelně není Hegel.

Kdo ale je jejím autorem? V dopise Schellingovi z 1. května $1807 \mathrm{He}-$ gel píše, že jeho spis, tj. zjevně Fenomenologie ducha, je konečně hotový, tj. vydaný, avšak že vydání bylo spojeno s problémy a zmatky týkajícími se tiskařské práce, a proto Schellingovi ještě neposlal exemplář své knihy, což brzy učiní. Dodává, že je zvědavý, co Schelling řekne na ideu této první části systému, jež je úvodem, protože dále než k úvodu - in mediam rem - se ještě nedostal. Dále píše, že s podobou knihy sám není spokojen, a zejména velká neforemnost (Unform) závěrečných částí je důsledkem toho, že redakční práce dokončoval o půlnoci před bitvou u Jeny. Dále se Hegel vyjadřuje o tom, co nás v naší souvislosti zajímá nejvíce: v souvislosti s předmluvou hovoří Hegel o plytkosti, která zejména s jeho, Schellingovými, formami provedla mnoho nesmyslů (Unfug) a jeho vědu (tj. filosofii) snížila na holý formalismus. V závěru dopisu považuje Hegel dokonce za nutné ujistit Schellinga o tom, že pokud by on - Schelling - ocenil pár stran jeho knihy, platilo by to pro něj víc, než kdyby s ní jiní byli spokojeni či nespokojeni jako s celkem, a že nezná nikoho jiného, od koho by si mohl přát uvedení své knihy publiku a soud o ní. ${ }^{37}$

$\mathrm{Z}$ tohoto celkového kontextu dopisu je patrné, že odkaz na holý formalismus není jen Hegelovou stylizací. Termín „holý formalismus“, jenž zjevně odpovídá termínu ,jednobarevný formalismus“ a termínu „přírodně-filosofický formalismus“ z předmluvy, neodkazuje tedy ke kritice Schellingovy identitní filosofie a filosofie př́rody zvláště, nýbrž k její deformaci, způsobené tím, že formy, tj. myšlenky, argumenty a sama metoda Schellingovy identitní filosofie, byly aplikovány způsobem, jenž Hegel popisuje v předmluvě a jenž jsme analyzovali. „Plytkost“", o které Hegel mluví, abstrahovala ze Schellingovy filosofie jednoduchou metodu, kterou neuváženě a bez reflexe aplikovala jako výkladový princip na všechno, s čím se setkala. Takto - nezamýšleně - vznikla ona parodie na Schellingovu filosofii př́rody, jak ji Hegel podává v předmluvě. Jejím autorem nebyl nikdo jiný než Schellingovi žáci. Jistý Röschlaub, lékař v Bamberku, Schellingovi píše:

„Nepochybuji, že máte dost nepřátel; avšak není jich ani tolik v zahraničí [tj. mimo Jeny a některých bližších okresů], a sotva by Vám

37 Srv. Briefe von und an Hegel, vyd. J. Hofmeister, I, 1785-1812, Hamburg 1952, str. $161 \mathrm{n}$. 
mohli mimo Jeny být ku škodě. To, co je proti Vám v jiných provinciích, to je spíše mylná představa, kterou si člověk udělá o Vašem systému, než že by byl prímo zaujatý proti Vám. Představuje si přitom nejpodivnější věc, jež se od zrodu šílenství liší jen souvislostí. ... To, co k tomu svádí [vlivné osobnosti], to nejsou v žádném př́padě Vaše spisy, nýbrž Vaši posluchači nebo vlastní žáci. Kdo z rozumných lidí sám čte Vaše spisy, ten Vás má v úctě. Avšak posuzuje-li Vás někdo podle mnoha Vašich žáků, kteří toho tolik hlubokomyslně nažvanili [brambarbasiren], může sotva soudit jinak..." ${ }^{\text {"38 }}$

Tilliette k tomu poznamenává, že to jsou „moudrá slova“, a vyjadřuje mínění, že Hegel sám, aniž by to ovšem často vyslovoval, rozlišoval mezi učiteli a žáky, a že Schelling bude později hořce litovat škod, které mu tito horlivci způsobili. ${ }^{39}$ Tento rozdíl je zjevně implicitně ve hře i v rámci Hegelovy kritiky monotónního formalismu v předmluvě, jak o tom výmluvně svědčí citovaný Hegelův dopis Schellingovi z 1. května 1807. Z r. 1806 pocházejí Aforismy o filosofii přirody, k nimž Schelling připojil „kritické fragmenty“. O nich Xavier Tilliette říká, že se v rámci propozic filosofie prŕrody vyjímají poněkud méně kriticky, a že jim chybí jak kontext, tak také oprávnění, ba dokonce v nich Schelling podle něho uniká jen těsně neopatrnosti svých žáků. Ze všech vět, které Tilliette cituje, zmiňme pro ilustraci jen jednu: „Sůl je indiferencí všech dynamických potencí v magnetismu, stejně jako (jednostranná) voda v elektricismu. “40 Tato věta se prŕíliš neliší od parodie, kterou uvádí Hegel v předmluvě, a ve vypracované podobě identitní filosofie př́rody, např. ve Würzburgských přednáškách, se nic podobného nenachází.

$\mathrm{Na}$ Hegelův dopis odpovídá Schelling teprve 2. listopadu. Píše, že spousta jiných záležitostí mu dosud nedovolila knihu, kterou mezitím obdržel, prostudovat a že zatím přečetl jen předmluvu. Schelling Hegelovi píše, že ,polemickou část“ předmluvy, čímž je s největší pravděpodobností míněna zmiňovaná kritika monotónního formalismu, nevztahuje na sebe, nýbrž na zneuživatele a pomlouvače, přestože v předmluvě, poznamenává Schelling, není tento rozdíl zmíněn. Nicméně v jedné věci se ohlašuje rozkol, jenž Schelling zatím interpretuje pouze jako nedorozumění. Vztahuje se k těm místům v předmluvě, na nichž Hegel kritizuje

\footnotetext{
38 Citováno podle X. Tilliette, Schelling, str. 119 n.

39 Tamt., str. 120.

40 Tamt., str. 185.
} 
pojem intelektuálního názoru jako prostředku k bezprostřednímu uchopení absolutní pravdy:

„To, v čem skutečně zastáváme odlišné přesvědčení nebo jiný názor, lze mezi námi nalézt a rozhodnout bez smírení krátce a jasně; nebot' smířit lze pochopitelně všechno, kromě jednoho. Tak doznávám, že až dosud nechápu smysl, s nímž oponuješ pojmu názoru. Nemůžeš jím přece mínit nic jiného než to, co Ty i já jsme nazvali ideou, jejíž povahou právě je, že má jednu stranu, ze které je pojmem, a druhou, ze které je názorem.“"41

Frank dodává, že na tento velmi prátelský Schellingův dopis Hegel neodpověděl, a vědomě se tak vyhnul navržené diskusi o vztahu pojmu a názoru. ${ }^{42}$ To je jistě škoda, nebot' se zdá, že idea má pro Schellinga v epistemologickém kontextu podobnou povahu jako Kantovo schéma: jeho úkolem je prostředkovat mezi pojmem a názorem, a aby mohlo tuto funkci splnit, musí být z jedné strany stejnorodé s názorem, $\mathrm{z}$ druhé s pojmem. Pokud míní Schelling v této formulaci názorem jeho smyslovou podobu, pak by tím říkal, že idea jakožto intelektuální názor má prostředkovat mezi pojmem a smyslovým názorem. At' už je tomu jakkoliv, zřejmé je, že slovy „co Ty i já jsme nazvali ideou“ Schelling odkazuje Hegela na společnou diskusi o statusu intelektuálního názoru, na jejímž základě dospěli ke shodě ohledně jeho povahy. ${ }^{43} \mathrm{Z}$ hlediska Hegelovy

41 Briefe von und an Hegel, str. 194.

42 M. Frank, Der unendliche Mangel an Sein, str. 153.

43 V článku O konstrukci ve filosofii, který vyšel v Kritickém žurnálu filosofie v r. 1802, Schelling o Kantovi píše: „Existuje jiná idea obecna, kterou Kant nezná a nepředpokládá, bez ohledu na to, že vysvětlení filosofie, jež bylo nepochybně rozvrženo podle této ideje, bere z tradice, idea, podle které lze filosofii ovšem označit jako znázorněni zvláštního v obecném. Obecno je zde bytostně a absolutně obecnem, není pojmem, nýbrž ideou, která, pokud myslíme obecné a zvláštní jako reflexivní protiklady v Kantově smyslu, obecné a zvláštní opět v sobě zahrnuje (begreift), stejně jako zvláštní v tom smyslu, jak se vyskytuje v geometrii, kromě zvláštního jakožto formálního faktoru v sobě zahrnuje (in sich faßt) opět také obecné. V tomto smyslu je ale obecné jakožto jednota obecného a zvláštního pro sebe sama již předmětem názoru, rozumí se čistě intelektuálního jakožto idea." Srv. F. W. J. Schelling, Über die Konstruktion in der Philosophie, in: S. Dietzsch (vyd.), Kritisches Journal der Philosophie, str. 206 n. Schelling vydával Kritický žurnál filosofie spolu s Hegelem. Je tudíž velmi nepravděpodobné, že by Hegel toto místo z Schellingova článku neznal. Navíc je téměř jisté, že vydavatelé spolu diskutovali o problémech, o nichž ve svých článcích pojednávali. Na citovaném místě pojímá Schelling ideu stejně jako v dopise Hegelovi, totiž jako jednotu obecného a zvlášt- 
kritiky tohoto pojmu v předmluvě je podstatné, že intelektuální názor obsahuje podle Schellinga pojmový, tedy diskursivní moment, což Hegel v předmluvě intelektuálnímu názoru upírá. A jelikož je z citovaného dopisu zřejmé, že toto Schellingovo pojetí bylo Hegelovi známé, pak máme důvod se domnívat, že ani kritika pojmu intelektuálního názoru v předmluvě nemiří v prvé řadě - pokud vůbec - na Schellinga. A to proto, že Hegelova kritika tohoto pojmu v předmluvě je založena na - kantovsky inspirované - striktní diferenciaci mezi bezprostředností intuitivity a zprostředkovaností diskursivity, což zjevně neodpovídá interpretaci tohoto pojmu, na kterou upomíná Schelling Hegela v dopise. ${ }^{44}$

Důvody, které vedly Hegela k tomu, aby se v předmluvě k Fenomenologii ducha vztahoval k Schellingovi jako k prrítomnému v nepř́tomnosti, nesouvisí tedy jen s tím, že zde chce udržet neadresný tón „obecného ducha“, jenž je ,živlem“ filosofie, jak by řekl Hegel, nýbrž také a možná především s tím, že metafora noci, ve které jsou všechny krávy černé, není namířena proti Schellingově identitní koncepci absolutna. Je namírena spíše proti směru, který ze Schellingovy identitní filosofie sice odvozuje svůj původ, avšak petrifikoval ji do natolik zjednodušené a formalistní podoby, jež se př́liš neliší od její parodie. Vznikla tak tzv. romantická

ního, pojmu a názoru, přičemž idea je intencionálním objektem intelektuálního názoru. Je tudíž pravděpodobné, že Schelling v dopise odkazuje Hegela na svůj článek $O$ konstrukci, a že se tedy oba kolem r. 1802 shodovali ohledně statusu ideje. Dodejme, že Hegel pojímá ideu jako jednotu obecného a zvláštního ještě i ve Vědě o logice. Navíc by to znamenalo, že kolem r. 1802 nemá Hegel ještě žádné výhrady vůči pojmu intelektuálního názoru, což odpovídá tomu, co Hegel říká ve Spisu o diferenci o transcendentálním názoru jako nutné podmínce filosofie.

44 Frank upozorňuje na to, že Hegel v kapitole o metodě ve Vědě o logice rehabilituje pojem intelektuálního názoru, ba že dokonce „zahanbeně přiznává“ správnost Schellingovy výhrady, která spočívá v tom, že má-li se pojem (či idea) na konci své cesty poznat jako to, čím je, musel mít od začátku implicitní znalost sebe sama. Srv. M. Frank, Schelling, Hegel, Marx, in: Schelling-Studien, 4, 2016, str. 135. Podle Franka to však znamená, že myšlenku subjektivity (Selbst) nelze odvodit v sérii kroků bezpředpokladově z asubjektivního bytí (selbstloses Sein), protože toto domněle asubjektivní bytí musí být myšleno jako sebevztah, a sice jako pojem sebevztahu, a to jako takový pojem, který kromě sebevztahu má - byt' nereflektovanou - znalost sebe sama. Srv. tamt. To je sice korektní výhrada, jen není jisté, zda postihuje Hegelovu logiku, nebot' to, co se ve Vědě o logice pohybuje, je pojem sám, čímž Hegel míní obdobu Kantovy transcendentální subjektivity, takže ani na samém počátku logiky není něco, co by bylo zcela prosto subjektivity. Věda o logice je pak popisem stále komplexnějších forem sebepoznání, přičemž každé z těchto forem odpovídá čisté myšlenkové určení jakožto pojmová struktura tohoto sebepoznání. K tomu srv. J. Karásek, Metoda jako sebevztah pojmu. K Hegelovu pojetí dialektické metody, in: Filosofický časopis, 61, 2013, str. 681-704. 
naturfilosofie, vůči které se filosofové a historici filosofie a vědy zejména v anglosaských zemích vymezovali a vymezují dodnes. ${ }^{45}$

\section{ZUSAMMENFASSUNG}

In der Vorrede zur Phänomenologie des Geistes gibt es Abschnitte, die laut den gängigen Interpretationen als eine implizite Kritik Hegels an Schellings Identitätsphilosophie, insbesondere seiner Naturphilosophie, aufgefasst werden. Die Absicht des Verfassers ist es darzulegen, dass aus systematischen Gründen sowie aus Gründen, die aus der Korrespondenz Schellings mit Hegel hervorgehen, diese traditionelle Interpretation zumindest in Frage gestellt werden sollte. Dies betrifft zuvörderst die berühmte Metapher der „Nacht“, in der ,,alle Kühe schwarz sind“, auf deren Interpretation sich der Verfasser u.a. konzentriert.

SUMMARY

In the Preface to the Phenomenology of Spirit, we find passages commonly perceived as an implicit critique of Schelling's philosophy of identity, and in particular his philosophy of nature. The aim of the article is to prove that there are both systematic reasons and reasons that can be found in the correspondence between Schelling and Hegel which, at least, cast doubt on this traditional interpretation. This concerns above all the metaphor of "night in which all cows are black" the interpretation of which is, among others, in the centre of author's argumentation.

45 Srv. např. M. Ruse, Charles Darwin. Filosofické aspekty Darwinových myšlenek, přel. J. Šafránek, Praha 2011. Na str. 194 Ruse konstatuje: ,Za Darwinovými myšlenkami (stejně jako myšlenkami jeho čtenářů) stálo německé hnutí z počátku devatenáctého století, které si říkalo prŕrodní filosofie (Naturphilosophie). Prosazovali ji filosofové, jako Friedrich Schelling a G. W. F. Hegel, i vědci, jako například Lorenz Oken a básník, pisatel listů a myslitel Johann Wolfgang von Goethe.“ Ke kritice označení „,naturfilosofie“ srv. R. Spaemann - R. Löw, Účelnost jako filosofický problém. Dějiny a znovuobjeveni teleologického myšlení, přel. K. Šprunk, Praha 2004, str. 151. K pojmu romantické př́írodní filosofie srv. M. Sobotka, Hegelova teorie přirodních procesü, in: týž, Stati k Hegelově Fenomenologii a filozofii práva, Praha 1993, str. 96-104. Sobotka zde rovněž srovnává Schellingovu a Hegelovu filosofii přírody a poukazuje k Leibnizovu vlivu na Hegela.

Článek je výstupem grantového projektu „Duch, prríroda a společnost v německé klasické filosofii“ (GAČR č. 16-11880S). 